\title{
Is there any relation between intrauterine growth restriction and platelet distribution width (PDW), platelet crit (PCT), mean platelet volume (MPV)? A prospective study
}

\section{Intrauterin gelişme geriliği ile trombosit dağılım genişliği (PDW), platelet crit (PCT), ortalama trombosit hacmi (MPV) arasında bir ilişki var mı? Prospektif bir çalışma}

Cemile Dayangan Sayan, Mahmut İlkin Yeral

Kırıkkale University Faculty of Medicine, Department of Obstetrics and Gynecology, Kırıkkale, Turkey

Geliş Tarihi: 08.02.2018

Kabul Tarihi: 13.02.2018

Doi:10.21601/ortadogutipdergisi.391962

\begin{abstract}
Aim: Intrauterine growth restriction (IUGR) is still an important pregnancy complication bringing on perinatal mortality and morbidity. Placental vascular dysfunction and subsequent obliteration of placental blood vessels are mostly accepted etiopathological factors of intrauterine growth restriction similar with preeclampsia. We aimed to investigate the possible difference between pregnant women suffering from intrauterine growth restriction and healty pregnant women for parameters of platelet count, platelet crit, platelet distribution crit and mean platelet volume.

Material and Method: This case- control study was conducted with 179 pregnant women. The study population was consisted of 94 pregnant women complicated with idiopathic IUGR (study group) and 85 healty pregnant women (control group). IUGR group was divided in two subgroups according to umbilical artery doppler velocimetry measurements. Complete blood count parameters including hemoglobin, platelet count, platelet distribution width (PDW), platelet crit (PCT), mean platelet volume (MPV) and white blood cell count (WBC) were measured.

Results: There was no significant difference between the groups for parameters of hemoglobin, PC and PCT. The mean amniotic fluid index of IUGR group was significantly lower than the control group $(\mathrm{p}=0.000)$. The mean WBC, MPV and PDW levels of IUGR group were significantly higher than the control group ( $\mathrm{p}=0.013, \mathrm{p}=0.047$ and 0.035 , respectively). The mean MPV level of IUGR group 1(umbilical artery $\mathrm{S} / \mathrm{D}>3$ ) was significantly higher than that of IUGR group 2 (umbilical artery $\mathrm{S} / \mathrm{D}<3)(\mathrm{p}=0.045)$.

Conclusions: In the present study, we observed a significant difference between IUGR and healty pregnant women for platelet parameters of MPV and PDW. Beside this, we also observed higher MPV values in IUGR patients with increased umblical artery resistance compared to that in IUGR patients with normal umblical artery blood flow. Further studies are needed to discuss our results.
\end{abstract}

Keywords: Intrauterine growth restriction, pregnancy, platelet 
Intrauterin gelişme geriliği ile trombosit dağılım genişliği (PDW), platelet crit (PCT), ortalama trombosit hacmi (MPV) arasında bir ilişki var mı? Prospektif bir çalışma

\section{Öz}

Amaç: İntrauterin gelişme geriliği (IUGR) günümüzde halen önemli bir gebelik komplikasyonu olup, perinatal mortalite ve morbiditeye neden olur. Plasental vasküler disfonksiyon ve bunu takiben plasental kan damarlarının obliterasyonu, preeklampsi ile benzer şekilde çoğunlukla intrauterin büyüme kısıtlamasının etyopatolojik faktörleri olarak kabul edilmektedir. Bu çalışmada intrauterin gelişme geriliği olan gebeler ile sağlıklı gebeler arasında trombosit sayısı, trombosit kriteri, trombosit dağılım kriteri ve ortalama trombosit hacmi parametreleri açısından olası farkın araştırılması amaçlandı.

Gereç ve Yöntem: Bu vaka kontrol çalışması 179 gebe ile yürütülmüştür. Çalışma popülasyonu, idiyopatik IUGR ile komplike olan 94 gebe (çalışma grubu) ve 85 sağlıklı gebeden (kontrol grubu) oluşmaktadır. IUGR grubu umbilikal arter doppler velosimetri ölçümlerine göre iki alt gruba ayrıldı. Hemoglobin, trombosit sayısı, PDW, PCT, PC, MPV ve beyaz küre sayısı (WBC) gibi tam kan sayımı parametreleri ölçüldü.

Bulgular: Hemoglobin, PC ve PCT parametreleri açısından gruplar arasında anlamlı fark yoktu. IUGR grubunun ortalama amniotik sıvı indeksi kontrol grubuna göre anlamlı derecede düşüktü $(\mathrm{p}=0.000)$. IUGR grubunun ortalama WBC, MPV ve PDW değerleri kontrol grubundan anlamlı derecede yüksekti (sırasıyla $p=0.013, p=0.047$ ve $\mathrm{p}=0.035$ ). IUGR 1. Grubunun (umbilikal arter $\mathrm{S} / \mathrm{D}>3$ ) ortalama MPV düzeyi IUGR 2. Grubununkinden (umbilikal arter $\mathrm{S} / \mathrm{D}<3)$ anlamlı derecede yüksekti $(\mathrm{p}=0.045)$.

Sonuçlar: Bu çalışmada, MPV ve PDW değerleri açısından IUGR olan gebeler ile sağlıklı gebeler arasında anlam11 bir farklılık olduğunu gözlemledik. Bunun yanında, normal umblikal arter kan akımına sahip IUGR hastalarıyla karşılaştırıldığında, umblikal arter direncinde artış bulunan IUGR hastalarında MPV değerleri daha yüksekti. Sonuçlarımız tartışmak için yeni çalışmalara ihtiyaç bulunmaktadır.

Anahtar Kelimeler: İntrauterin gelişme geriliği, gebelik, platelet

\section{Introduction}

Intrauterine growth restriction (IUGR) is still an important pregnancy complication bringing on perinatal mortality and morbidity and affects $10-15 \%$ of pregnant women [1]. IUGR is mostly described as the estimated fetal weight (EFW), measured by ultrasonoghraphically, being under 10th percentile for gestational age using populationspecific fetal growth curves [2]. Prematurity is the first most frequent reason of the perinatal mortality and IUGR is the second. Stillbirth is a very annoying condition for the obstetricians and stillbirth rates of IUGR babies are 5-10 fold more frequent with an incidence of 23-65\% than normal babies [1]. A quarter of all stillbirths are complicated with IUGR [1]. Various factors could affect the risk of fetal death with growth restriction such as gestational age, the amniotic fluid level, umbilical artery and middle cerebral artery doppler ultrasound evaluation and the etiology of IUGR [3].

Althoughtherearemany studies focused on etiopathogenesis of IUGR, $70 \%$ of IUGR cases are called 'idiopathic'. In other $30 \%$ of IUGR cases, several etiologic factors could be mentioned such as maternal hypertension, diabetes mellitus, cardiopulmonary disease, anemia, malnutrition, smoking and drug addiction, high altitude, irradiation, fetal genetic abnormalities, congenital malformations, multiple pregnancy, placental insufficiency, placental infarct, placental mosaicism [3]. It has been reported that the most frequent reason of IUGR is the deficiency of placenta. If necessary nutrients and oxygen do not pass from the maternal blood to fetal circulation by placenta, satisfactory fetal development could not occur [4].

Mean platelet volume (MPV), platelet distribution width (PDW), platelet count (PC) and platelet crit (PCT) are mostly known as markers of platelet activation and show platelet volume variation [5]. It has been reported that platelet parametersarerelated to cardiovasculardiseases, hypertension, diabetes mellitus and inflammatory bowel diseases $[6,7,8]$. It has also been shown that these platelet parameters are related to development and severity of preeclampsia $[8,9,10]$. It is not clear yet how platelet parameters change on the patients suffering from these disease; but increased MPV, PDW and PCT levels are considered to be associated with continuing inflammation $[8,11]$. 
Placental vascular dysfunction and subsequent obliteration of plasental blood vessels are mostly accepted etiopathological factors of IUGR similar with preeclampsia [12]. So that, we aimed to investigate the possible difference between pregnant women suffering from IUGR and healty pregnant women for parameters of MPV, PDW, PC and PCT.

\section{Material and Method}

This case- control study was conducted with 179 pregnant women attended pregnancy out-patient clinic between May 2016-May 2017. The study population was consisted of 94 pregnant women complicated with idiopathic IUGR (study group) and 85 healty pregnant women (control group). All pregnant patients were in the third trimester of the gestation. The research protocol was approved by the Ethics Committee of Kırıkkale University in Kırıkkale and all patients gave informed consent. The study was carried out in accordance with the Declaration of Helsinki Principles.

Gestational age was calculated via the first day of last menstruation and first trimester ultrasonography measurements. According to serial fetal ultrasound examination, fetal weight under the 10th percentile for gestational age was considered as IUGR. Exclusion criteria for both study and control groups were as follows; smoking, multiple gestations, hypertensive disorders of pregnancy, gestational or non-gestational diabetes mellitus, hereditary or acquired thrombophilia, congenital abnormalities, premature rupture of membranes, systemic or local infection documented with culture studies, active labor, otoimmune disorders and medication with immune supressor or modulator. Control group was consisted of age, gestational week and body mass index (BMI) matched pregnant women. The demographic characteristic of patients were noted including age, gravidity, gestational week and BMI. Clinical examination and fetal evaluation by obstetric ultrasound were performed for all pregnant patients. Ultrasonography examinations were performed with GE Healthcare, Voluson E8. Umbilical artery doppler velocimetry measurements were performed in pregnant patients with IUGR. IUGR group was divided in two subgroups according to umbilical artery doppler velocimetry measurements. Umbilical artery $\mathrm{S} / \mathrm{D}$ ratio higher than 3 was named as IUGR group 1 and umbilical artery S/D ratio lower than 3 was named as IUGR group 2 . The blood samples of all patients were collected during the routine antenatal visit in the third trimester of pregnancy and all patients had no medication before taking the blood sample. Complete blood count parameters including hemoglobin, PC, PDW, PCT, MPV and white blood cell count (WBC) were measured by using CELL-DYN Ruby analyzer (Abbott Laboratories, Abbott Park, IL, USA).

Antenatal care of all subjects were carried out until delivery. Timing of delivery were determined on a caseby-case basis and cesarean-section was performed only for obstetric indications.

\section{Statistics}

The software SPSS 16.0 (USA) version was used for the statistical analysis. Descriptive statistical methods; mean, standard deviation, median ( $\min -\max )$ were obtained. The distribution pattern of the data was determined by the Kolmogorow-Smirnov test. The Mann-Whitney U test was used to determine the statistical comparisions between the groups for continuous variables. And Chi-Square and Fisher exact test was used to compare the categorical variables between groups. A p value less than 0.05 was considered as statistically significant.

\section{Results}

The study population was consisted of 179 patients. The demographic and clinical characteristics of IUGR and control groups were shown in Table 1. There was no significant difference between the groups in terms of maternal age, BMI, gravidity and parity. The mean gestational week at delivery and birthweight of the IUGR group were significantly lower than those of control group $(p=0.003$ and 0.000 , respectively). Vaginal birth rate of control group was significantly higher than that of IUGR group $(\mathrm{p}=0.048)$ (Table 1).

Ultrasonographic and laboratory findings of IUGR and control groups were presented in Table 2. There was no significant difference between the groups for parameters of hemoglobin, PC and PCT. The mean amniotic fluid index (AFI) of IUGR group was significantly lower than the control group $(\mathrm{p}=0.000)$. The mean WBC, MPV and PDW levels of IUGR group were significantly higher than the control group $(\mathrm{p}=0.013, \mathrm{p}=0.047$ and 0.035 , respectively) (Table 2$)$.

The comparisions of the IUGR group 1 and 2 in terms of WBC, hemoglobin, PC, PCT, PDW, MPV and AFI were demonstrated in Table 3. There was no significant difference between subgroups for parameters of WBC, hemoglobin, PC, PDW and PCT. The mean AFI scores of the IUGR group 1 was significantly lower than that of IUGR group $2(p=0.001)$. The mean MPV level of IUGR group 1 was significantly higher than that of IUGR group $2(\mathrm{p}=0.045)$ (Table 3$)$. 
Intrauterin gelişme geriliği ile trombosit dağılım genişliği (PDW), platelet crit (PCT), ortalama trombosit hacmi (MPV) arasında bir ilişki var mı? Prospektif bir çalışma

Table 1. Demographic and clinical characteristics of IUGR and control groups.

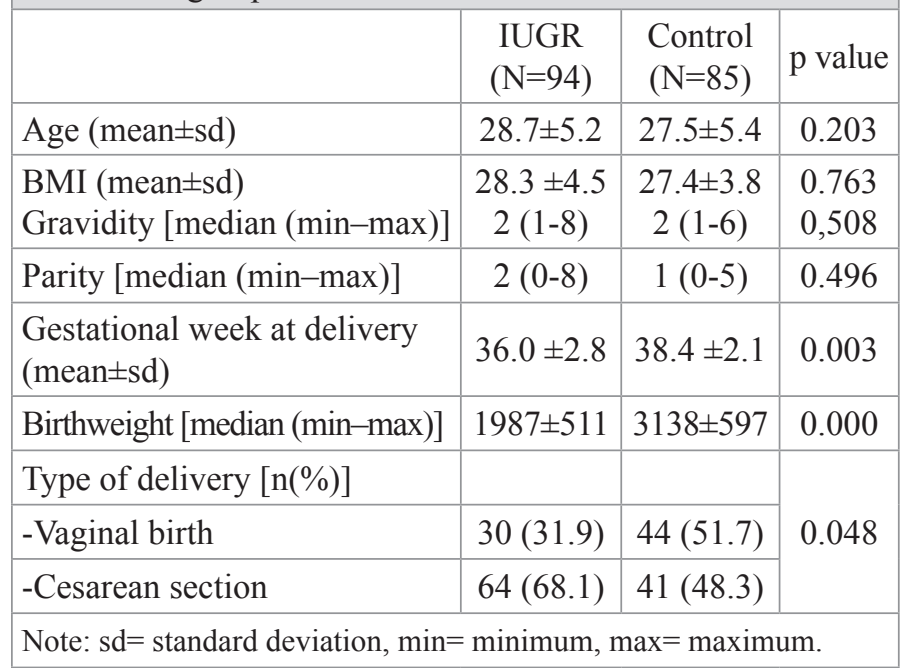

Table 2. Laboratory and ultrasonographic findings of IUGR and control groups

\begin{tabular}{|l|c|c|c|}
\hline & $\begin{array}{c}\text { IUGR } \\
(\mathrm{N}=94)\end{array}$ & $\begin{array}{c}\text { Control } \\
(\mathrm{N}=85)\end{array}$ & $\mathrm{p}$ value \\
\hline WBC $(\mathrm{X} 103 \mu \mathrm{l})$ & $11.8 \pm 3.5$ & $10.5 \pm 1.9$ & 0.013 \\
\hline Hemoglobin $(\mathrm{mg} / \mathrm{dl})$ & $11.2 \pm 1.6$ & $11.3 \pm 1.2$ & 0.979 \\
\hline PC $(\mathrm{X} 103 \mu \mathrm{l})$ & $206 \pm 64$ & $211 \pm 64$ & 0.603 \\
\hline PCT $(\%)$ & $0.200 \pm 0.50$ & $0.205 \pm 0.53$ & 0.578 \\
\hline PDW $(\%)$ & $17.5 \pm 1.2$ & $16.2 \pm 0.83$ & 0.035 \\
\hline MPV $(\mu \mathrm{m} 3)$ & $10.3 \pm 1.2$ & $8.4 \pm 0.9$ & 0.047 \\
\hline AFI $(\mathrm{mm})$ & $65 \pm 26$ & $108 \pm 37$ & 0.000 \\
\hline
\end{tabular}

Note: Values are presented as mean \pm standard deviation. $\mathrm{WBC}=$ white blood cell; $\quad \mathrm{PC}=$ platelet count $\mathrm{PCT}=$ platelet crit; $\mathrm{PDW}=$ platelet distribution crit; $\mathrm{MPV}=$ mean platelet volume; $\mathrm{AFI}=$ amniotic fluid index

Table 3. Comparison of the ultrasonographic and laboratory findings in IUGR subgroups

\begin{tabular}{|l|c|c|c|}
\hline & $\begin{array}{c}\text { IUGR } \\
\text { Group 1 } \\
(\mathrm{N}=31)\end{array}$ & $\begin{array}{c}\text { IUGR } \\
\text { Group 2 } \\
(\mathrm{N}=63)\end{array}$ & $\begin{array}{c}\mathrm{p} \\
\text { value }\end{array}$ \\
\hline WBC $(\mathrm{X} 103 \mu \mathrm{l})$ & $11.9 \pm 3.9$ & $11.8 \pm 3.4$ & 0.938 \\
\hline Hemoglobin $(\mathrm{mg} / \mathrm{dl})$ & $11.5 \pm 1.7$ & $11.1 \pm 1.3$ & 0.462 \\
\hline PC $(\mathrm{X} 103 \mu \mathrm{l})$ & $196 \pm 50$ & $210 \pm 70$ & 0.398 \\
\hline PCT $(\%)$ & $0.208 \pm 0.055$ & $0.183 \pm 0.045$ & 0.937 \\
\hline PDW $(\%)$ & $17.6 \pm 0.9$ & $17.1 \pm 0.6$ & 0.292 \\
\hline MPV $(\mu \mathrm{m} 3)$ & $10.3 \pm 1.5$ & $9.5 \pm 0.9$ & 0.045 \\
\hline AFI $(\mathrm{mm})$ & $50 \pm 21$ & $72 \pm 25$ & 0.001 \\
\hline
\end{tabular}

Note: IUGR Group 1= umbilical artery S/D $>3$; IUGR Group 2: umbilical artery $\mathrm{S} / \mathrm{D}<3$.

Values are presented as mean \pm standard deviation. $\mathrm{WBC}=$ white blood cell; $\mathrm{PC}=$ platelet count $\mathrm{PCT}=$ platelet crit; $\mathrm{PDW}=$ platelet distribution crit; $\mathrm{MPV}=$ mean platelet volume; $\mathrm{AFI}=$ amniotic fluid index

\section{Discussion}

This case-control study aimed to investigate the possible difference between pregnancies complicated with IUGR and healty pregnant women for parameters of PDW, PCT, MPV. We observed that WBC, MPV and PDW levels of pregnant women complicated with IUGR were significantly higher than those of healty pregnant controls, but PC and PCT levels did not differ between IUGR and control patients. When we divided the IUGR patients according to umbilical artery S/D ratio either higher or lower than 3; we found no difference in terms of $\mathrm{WBC}$, PDW, PC and PCT levels between IUGR subgroups, but the mean MPV level of IUGR group with high umbilical atrery doppler scores was significantly higher than that of IUGR group with normal umbilical artery doppler scores.

IUGR is still one of the most important cause of perinatal mortality and morbidity such as necrotizing enterocolitis, respiratory distress syndrome and intracranial hemorrhage. It has been reported that IUGR is responsible from $52 \%$ of intrauterine deaths and $10 \%$ of perinatal mortality due to diagnostic inaccuracy in term fetuses with IUGR $[13,14]$. Additionally, short and long term sequelae could occur as a result of IUGR and low birth weight contributed occuring these sequelae. Numerous conditions such as preeclampsia, karyotype anomalies, multiple gestations could cause IUGR but certain pathophysiological reason is not clarified yet [15]. Damaged and decreased uteroplacental perfusion is the mostly mentioned cause of interrupted fetal growth. Normal function of placental circulation is very important for maintaining fetal growth. Damaged uteroplacental perfusion provokes placental vascular obliteration leading to endothelial damage. Increased endothelial damage activates microthrombi generation and finally platelet breakdown and platelet turnover accelerate [16].

MPV, a routine parameter of complete blood count, demonstrates platelet size and relevant to platelet reactivity [17]. So it has been reported that MPV could be used as a marker of platelet activity during diagnosis of cardiovascular diseases [18]. Large platelets, the marker of platelet reactivity, are seen most frequent in certain cases such as cardiovascular diseases and prothrombotic events. On the other hand, small platelets are generally seen in chronic diseases such as rheumatoid artritis and systemic lupus erythematosus [11]. In recent studies, the relationship between IUGR and MPV has been 
investigated. Kanat-Pektas et al. reported that MPV values of $10.5 \mathrm{fl}$ or more can predict IUGR with $82.4 \%$ sensitivity and $60.0 \%$ specificity. Visan et al. reported that MPV determination in the first trimester with clinical history and PAPP-A (Pregnancy-Associated Plasma Protein A) could reduce perinatal mortality and morbidity in pregnancies complicated with IUGR [19]. But Ureyen et al. reported in their retrospective study that there was no difference between MPV values of the IUGR and healthy pregnancy groups [12]. In our study we observed increased MPV values in IUGR group and also we observed higher MPV values in IUGR subgroup with umbilical artery $S / D>3$ than the IUGR subgroup with umblical artery $S / D<3$.

The morphological shape changes and reactivity of platelets are shown by RDW in complete blood count. When platelets activates, morphological changes of platelets start and new formations occur such as spherical transformation and pseudopodial formation. As a result of this process many different size of platelets could be detected and PDW values increase as expected. [20]. Akingbola et al. reported that decreament in PDW values during pregnancy is an expected situation [21]. In contrast to this study, Lurie et al. showed that platelet activation values such as PDW are higher in pregnant women than that of non-pregnant women (22). Karateke et al. investigated PDW values in preeclamptic patients and they reported that PDW values were higher than normal pregnant women [11]. It has been also reported that IUGR and preeclampsia are caused by similar placental vascular pathologies and thrombophilic disorders [23]. Therefore in this study we investigated the PDW difference between pregnancies complicated with IUGR and normal pregnancies. We observed that researchers have focused on only MPV values in pregnancies complicated with IUGR $[12,16]$. According to our results, PDW values in pregnancies complicated with IUGR were significantly higher than healty pregnancies. On the otherhand there was no significant difference for PDW values between IUGR subgroups according to umblical artery S/D ratio.

PCT is mainly accepted as a yield of platelet count and MPV and corresponds to the volume that platelets have in $100 \mathrm{~mL}$ of total blood [10]. It is usually accepted as correspondent to the hemothocrit. Feritas et al. and Karateke et al. reported that in preeclamptic pregnancies PCT levels significantly lower than normal pegnancies (Freitas, Karateke). Because of the hypothesis that preeclampsia and IUGR have similar pathogenesis, in this study we also examined PCT values of groups. We found no significant difference in terms of PCT values between IUGR and healty pregnancies.

In literature there are numerous studies investigated the relationship between MPV and pregnancy complications related to vascular diseases such as preeclampsia, ablatio placenta and IUGR [12,23,24]. There are also studies investigated the association between preeclampsia and RDW, PCT and other platelet parameters [25,26]. But there is no study investigated the association between IUGR and RDW and PCT. This is the main finding of this study. Also the prospective design of the study is an advantage, too. It could be mentioned as a limitation of this study that we could not evaluate the association between perinatal complications and MPV, PDW, PCT values.

In conclusion, in the present study, we observed a significant difference between IUGR and healty pregnant women for platelet parameters of MPV and PDW which are the indicators of inflammation and placental vascular dysfunction. Beside this, we also observed higher MPV values in IUGR patients with increased umblical artery resistance compared to that in IUGR patients with normal umblical artery blood flow. Measurement of platelet parameters as a part of complete blood count is an easy, simple and cost effective tool. We think that MPV and PDW values could be used for predicting the diagnosis of IUGR. Further studies are needed to investigate the role of MPV and PDW values for predicting the diagnosis of IUGR and its perinatal complications.

\section{Acknowledgements}

We thank to Zehra Sema Ozkan for contributing to writing the paper.

\section{Declaration of interest}

The authors report no conflicts of interest. The authors alone are responsible for the content and writing of this article. 


\section{References}

1. Dikbas L, Yapca OE, Dikbas N, Gundogdu C.Paraoxonase-2 and paraoxonase-3: comparison of mRNA expressions in the placentae of unexplained intrauterine growth restricted and noncomplicated pregnancies. J Matern Fetal Neonatal Med 2017;30 (10):1200-6.

2. Restriction IG. ACOG Practice Bulletin No. 12. Washington, DC: American College of Obstetricians and Gynecologists; 2000.

3. Suhag A, Berghella V. Intrauterine growth restriction (IUGR): etiology and diagnosis. Curr Obstet Gynecol Rep 2013;2:102-11.

4. Sankaran S, Kyle PM. Aetiology and pathogenesis of IUGR. Best Pract Res Clin Obstet Gynaecol 2009;23:765-77.

5. Jackson SR, Carter JM. Platelet volume: laboratory measurement and clinical application. Blood reviews 1993;7 (2):104-13.

6. Boos CJ, Beevers GD, Lip GY. Assessment of platelet activation indices using the ADVIATM 120 amongst, high-risk' patients with hypertension. Annals of medicine 2007;39 (1):72-8.

7. Akpinar I, Sayin MR, Gursoy YC et al. Plateletcrit and red cell distribution width are independent predictors of the slow coronary flow phenomenon. Journal of cardiology $2014 ; 63$ (2):112-8.

8. Ozturk ZA, Dag MS, Kuyumcu ME et al. Could platelet indices be new biomarkers for inflammatory bowel diseases? European review for medical and pharmacological sciences 2013;17 (3):334-41.

9. Marumoto Y, Kaibara M, Murata T. Hemorheological studies on platelet counts and size in normal pregnancy and pregnancies with preeclampsia and intrauterine growth retardation. Nihon Sanka Fujinka Gakkai Zasshi 1989;41:1380-6.

10. Freitas LG, Alpoim PN, Komatsuzaki F, et al. Preeclampsia: are platelet count and indices useful for its prognostic? Hematology 2013;18:360-4.

11. Karateke A, Kurt RK, Baloğlu A. Relation of platelet distribution width (PDW) and platelet crit (PCT) to preeclampsia. Ginekol Pol 2015;86 (5):372-5.

12. Ureyen I, Ozyuncu O, Sahin-Uysal N et al. Relationship of maternal mean platelet volume with fetal Doppler parameters and neonatal complications in pregnancies with and without intrauterine growth restriction. J Matern Fetal Neonatal Med 2017 ;30 (4):471-4.

13. Mandruzzato G, Antsaklis A, Botet F, et al. Intrauterine restriction (IUGR). J Perinat Med 2008;36:277-81.

14. Clausson B, Cnattingius S, Axelsson O. Outcomes of post-term births: the role of fetal growth restriction and malformations. Obstet Gynecol 1999;94:758-62.

15. Cunningham FG, Leveno KL, Bloom SL, et al. Fetal growth disorders. Williams obstetrics, Chapter 38. 22nd ed. New York: McGraw Hill; 2001:893-910.
16. Dundar O, Pektas MK, Bodur S, Bakır LV, Cetin A. Recurrent pregnancy loss is associated with increased red cell distribution width and platelet distribution width. J Obstet Gynaecol Res 2015 ;41 (4):551-8.

17. Yetkin E. Mean platelet volume not so far from being a routine diagnostic and prognosticmeasurement. Thrombosis and haemostasis 2008;100 (1):3-4.

18. Gasparyan AY, Ayvazyan L, Mikhailidis DP, Kitas GD. Mean platelet volume: a link between thrombosis and inflammation? Current pharmaceutical design 2011;17 (1):47-58.

19. Vişan V, Anghelache-Lupaşcu I, Sălăvăscu T et al. Intrauterıne growth restriction-predictıve serum markers. Rev Med Chir Soc Med Nat Iasi 2016 ;120 (1):173-7.

20. Jagroop IA, Clatworthy I, Lewin J, Mikhailidis DP. Shape change in human platelets: measurementwith a channelyzer and visualisation by electron microscopy. Platelets 2000;11 (1):28-32.

21. Akingbola TS, Adewole IF, Adesina OA et al. Haematological profile of healthy pregnant women in Ibadan, southwestern Nigeria. Journal of Obstetrics and Gynaecology. 2006;26:763-9.

22. Lurie S, Rigini N, Zabeeda D, Sadan O, Ezri T, Glezerman M. Changes in platelet function, volume and count during labor and 24 hours postpartum. Platelets 2003;14:355-8.

23. Arlier S, Adiguzel C, Yilmaz ES et al. The role of mean platelet volume and platelet distribution width in the prediction of placental abruption. J Obstet Gynaecol 2016;36 (7):950-3.

24. Mannaerts D, Heyvaert S, De Cordt C, Macken C, Loos C, Jacquemyn Y. Are neutrophil/lymphocyte ratio (NLR), platelet/ lymphocyte ratio (PLR), and/or mean platelet volume (MPV) clinically useful as predictive parameters for preeclampsia? J Matern Fetal Neonatal Med 2017;11:1-8.

25. Yücel B, Ustun B. Neutrophil to lymphocyte ratio, platelet to lymphocyte ratio, mean platelet volume, red cell distribution width and plateletcrit in preeclampsia. Pregnancy Hypertens. 2017;7:29-32.

26. Yılmaz ZV, Yılmaz E, Küçüközkan T. Red blood cell distribution width: A simple parameter in preeclampsia. Pregnancy Hypertens 2016;6 (4):285-7.

Corresponding author: Cemile Dayangan Sayan, Kırıkkale University Faculty of Medicine, Department of Obstetrics and Gynecology, Kırıkkale, Turkey

Phone: +905056755247

E-mail: c.dayangan-sayan@hotmail.com 